\title{
Tumor Results Completion Status
}

National Cancer Institute

\section{Source}

National Cancer Institute. Tumor Results Completion Status. NCI Thesaurus. Code C117422.

A term used to describe the state or condition of the completeness of the tumor results data. 